\title{
COASTAL ECOTOURISM MANAGEMENT FOR SUSTAINABLE DEVELOPMENT IN PANGGUL, TRENGGALEK REGENCY, EAST JAVA, INDONESIA
}

\author{
ESKA NIA SARINASTITI* AND MUHAMAD SIDIQ WICAKSONO \\ Department of Languages, Arts, and Culture Management, Vocational College, Universitas Gadjah Mada, 55281, \\ Yogyakarta, Indonesia.
}

*Corresponding author: eskanias@ugm.ac.id

Submitted final draft: 27 October $2020 \quad$ Accepted: 24 December $2020 \quad$ http://doi.org/10.46754/jssm.2021.08.022

\begin{abstract}
Coastal ecotourism management is a sustainable tourism development strategy that is beneficial for coastal areas in terms of socio-cultural, environmental, economic, and government aspects. This study aims to evaluate coastal ecotourism management in these six coastal areas in Panggul, Trenggalek Regency, East Java, Indonesia. The method of this study is qualitative evaluation research by collecting data through semi-structured interviews, direct observation, and documentation. Inductive analysis is conducted to process the data. The result of this study can be summarized that a) status of coastal management is divided to two types, under government and coastal community; b) economic opportunities in each beach depend on coastal resource, tourism facilities, and the local organization climate involved in the management of coastal tourism; c) community participation is needed realize social-wellbeing and local custom preservation; d) shrimp ponds and littering are threats for coastal environmental quality, which need sustainable management; e) The lack of involvement of the Trenggalek government in sustainable tourism development policies. Based on the result, the government's role in coastal ecotourism management and coastal zone management policies in each coastal area of Trenggalek must be strengthened for sustainable coastal tourism development.
\end{abstract}

Keywords: Coastal Ecotourism, Community Participation, Sustainable Tourism Development.

\section{Introduction}

Trenggalek regency in East Java, Indonesia, consists of 14 districts. One of the areas is Panggul, which is $131.56 \mathrm{~km}^{2}$, or $10.43 \%$ of the total area of Trenggalek regency. (Badan Pusat Statistik [BPS], 2019). Panggul is one of the three coastal regions connected to the southern coast in Trenggalek regency; the two other areas are Munjungan and Watulimo sub-district. However, Panggul is located at the lowest height of sea level, which is approximately $13 \mathrm{~m}$ (BPS, 2018). The uniqueness of Panggul lies in its district borders, where the Indonesian Ocean or Indian Ocean is to the southwest and Pacitan is to the northwest.

Panggul has six beaches that offer coastal tourism potential: Konang, Djoketro, Kuyon, Taman Kili-kili, Pelang, and Njorok. These six beaches are located in one coastline separated only by a promontory. The coastline is directly connected to the Indian Ocean, so that the waves are a high risk to tourist safety. Therefore, tourism activities tend to be coastal tourism. Tourist attractions focus on natural landscapes that include wetlands along the coast, coral reefs, and other fragile natural ecosystem components (Papageorgiou, 2016). Coastal tourism is the highest economic source for coastal and marine activities outside of fishing (Jones \& Phillip, 2016; United Nations Environment Program [UNEP], 2009). Tourism provides economic profit, but also puts pressure on ecosystem quality, even marginalization in local communities (Halim, 2017) Meanwhile, coastal tourism depends on the quality and diversity of the coastal environment, climate, scenery, ecosystem, and cultural tradition (UNEP, 2009; Jones \& Phillip, 2016).

Records of tourist visits are available only for Pelang, which is about 48,805 in 2015 (BPS, 
2017). It is the only beach managed by the local government Tourism Office of Trenggalek, while tourist figures for other beaches are not available. Pelang Beach has various facilities for tourism (accommodation, transportation, souvenir shops, information center, prayer room, parking sites, and toilet) and applied the seven principles of tourism, which include security, order, cleanliness, coolness, beauty, hospitality and memories (Muzaki, 2017). Nevertheless, construction there is unplanned and there is no guide that explains the attractions on Pelang Beach (Setyorahmah, 2017). The existence of Pelang Beach as a tourism destination has not provided permanent jobs to the local community, so residents need another job to meet their daily needs (Muzaki, 2017). The average number of visitors to Konang Beach is 67 tourists per day, but a ticket portal for tourists has not been available (Prasetyo, 2013). The hygiene and sanitation of Konang beach restaurants have not been well maintained, including the personal hygiene of employees, food and beverage, liquid waste, and the healthy environment guarantee (Wahyunanto \& Topowijono, 2018). Meanwhile, other beaches, Kili-kili, Djoketro, Kuyon and Jorok, have problems with accessibility and infrastructure. Kili-kili, a sea turtle conservation and education tourism center, has been touted as a marine eco-tourism destination, but faces some challenges in the lack of human resources. Only five volunteers staff the conservation centre and tourist facilities, such as souvenir, food and beverage shops, prayer room, toilet, telecommunication network, and parking sites, are not unavailable. The struggle for land ownership in Kili-kili between the Forestry Office and the Office of Marine Affairs and Fisheries has yet to be solved until now (Tuzaroh, 2015). Shrimp ponds built near the beaches of Panggul have affected its environmental quality. Eight farms exist in Konang, three in Djoketro, six near Taman Kili-kili, and one near Pelang.

Ecotourism is being carried out with the hope of sustainable tourism development by helping overcome problems in utilization patterns that damage the sustainability of coastal resources and protect natural resources that are sensitive to tourism development (Tuwo, 2011; Sarfaraz et al., 2015; Tegar \& Gurning, 2018). The concept of ecotourism is a journey that enjoys environmental life and focuses on building sustainable tourism that provides ecosystem sustainability, ecological conservation, education provision, economic and social life improvement, and cultural protection for local communities (Hakim et al., 2018; Tegar \& Gurning, 2018; Rudiastuti et al., 2018; Handayawati, 2010). Therefore, this research analyzes the implementation of coastal ecotourism management for sustainable tourism development in Panggul, Trenggalek.

\section{Coastal Ecotourism Management and Sustainable Tourism}

The challenges of managing coastal tourism include resource consumption and competition, both of which encourage the use of living land for business and affect the livelihood and well-being of local communities and their local culture (World Tourism Organization [WTO], 2013). Reducing damage on coral reefs and increasing adaptive capacity of coastal tourism are feasible by involving conservation, strengthening knowledge, education, mitigation measures, and planning effective strategies and community participation (Riniwati, Harahab, \& Abidin, 2019). Environmental issues threaten the benefits that local communities can gain from their surrounding ecosystem. Therefore, the initial coastal management plan related to governance and conflict over coastal resource use must resolve such issues. The lack of regulation to manage, protect and maintain fisheries or consumptive forms, such as controlling the number of visitors and boat mooring area, can affect the success of management, which can influence heritage values and business viability (Gollan et al., 2019).

There are four evaluation dimensions of coastal ecotourism management, comprising ecological or environmental quality, social wellbeing, economic, and institutional dimensions of governance in management (Karnauskaite et al., 2018; Nuzula et al., 2017; Mcelduff et al., 2016). Environmental quality is evaluated on the 
basis of air pollution, conservation (biodiversity and natural resources management), green policy, open view, land use, sustainable transportation, waste management, climate change adaptation, water management, public health, and security (Schernewski et al., 2014; SUSTAIN partnership, 2012). Environmental cleanliness must be maintained, and buildings along the coast should be minimized. Habitats along the coast, such as mangroves, seaweeds, coral reefs and sea fishes must also be conserved (Halim, 2017).

Economic indicators are evaluated on the basis of economic opportunity, land use, tourist destination management, hospitality and satisfaction, and transportation. (Schernewski et al., 2014; SUSTAIN partnership, 2012). Meanwhile, the social well-being of communities can be seen from the equal opportunities in improving quality of social life and the conservation of cultural heritage, providing opportunities to obtain proper education and knowledge about sustainability, providing protection from crimes, and reducing the vulnerability of local communities to climate change (Karnauskaite et al., 2018). Social wellbeing, community management, and cultural identity indicators can be evaluated on the basis of demographics, equity, education and training, local cultural identity, public health and security, community participation, community tradition, and cultural heritage (Schernewski et al., 2014; SUSTAIN partnership, 2012). The participation and understanding of local communities on economic, social, and knowledge issues are the basis for the formation of community-based government policies (Masud, Aldakhil, Nassani \& Azam, 2017). Community participation is an important component of successful coastal management. The awareness of communities around the conservation of natural resources creates the sustainability of coastal resources (Famuditi, 2016; Bambang, 2018). Community resilience and coastal regeneration for sustainability must have the values of these four dimensions, especially governance, to produce policies related to socio-ecological regeneration. Such policies can encourage community development that is sustainable according to the needs of the communities and their natural environment (Mcelduff et al., 2016). Hakim et al. (2018) revealed that nature tourism requires the participation of local communities in its development to be attentive, responsible, and committed to preserving the environment and local culture.

Governments are responsible for planning and developing coastal tourism zones by minimizing the impact of buildings on the natural environment; thus, the government must also provide sewerage disposal facilities and security services for tourists. (UNEP, 2009). In addition, governments should provide learning and training services to improve participants' sensitivity and ability (Seba, 2012). Governance indicators are based on policies or strategies and monitoring tools for sustainability, capacity building for human resource, good governance management practice, and stakeholder involvement (Schernewski et al., 2014; SUSTAIN partnership, 2012). Based on the literature studies, coastal ecotourism requires strategic management for sustainability that includes economic opportunities, environmental quality, social-wellbeing preservation, community participation, and government roles.

\section{Study Area}

Panggul has three villages directly adjacent to the sea, namely, Wonocoyo, Nglebeng, and Besuki. But Besuki village is bounded by mountainous cliffs therefore, Wonocoyo and Nglebeng villages, both of which have coastal areas, are the primary research areas. Wonocoyo is a $6.78 \mathrm{~km}^{2}$ village at 8,244872 latitude and 111.4535 east longitude, $10.4 \mathrm{~m}$ above sea level.

Nglebeng village has an area of 22.18 $\mathrm{km}^{2}$, is located at 8,25053 south latitude and 111.45808 east latitude, and is $11.6 \mathrm{~m}$ above sea level. Both villages have the lowest sealevel elevation among other villages in the area, (Figure 1). Nglebeng village consists of Konang, Djoketro, and Kuyon beaches. Wonocoyo village comprises Taman Kili-kili, Pelang and Njorok beaches. 


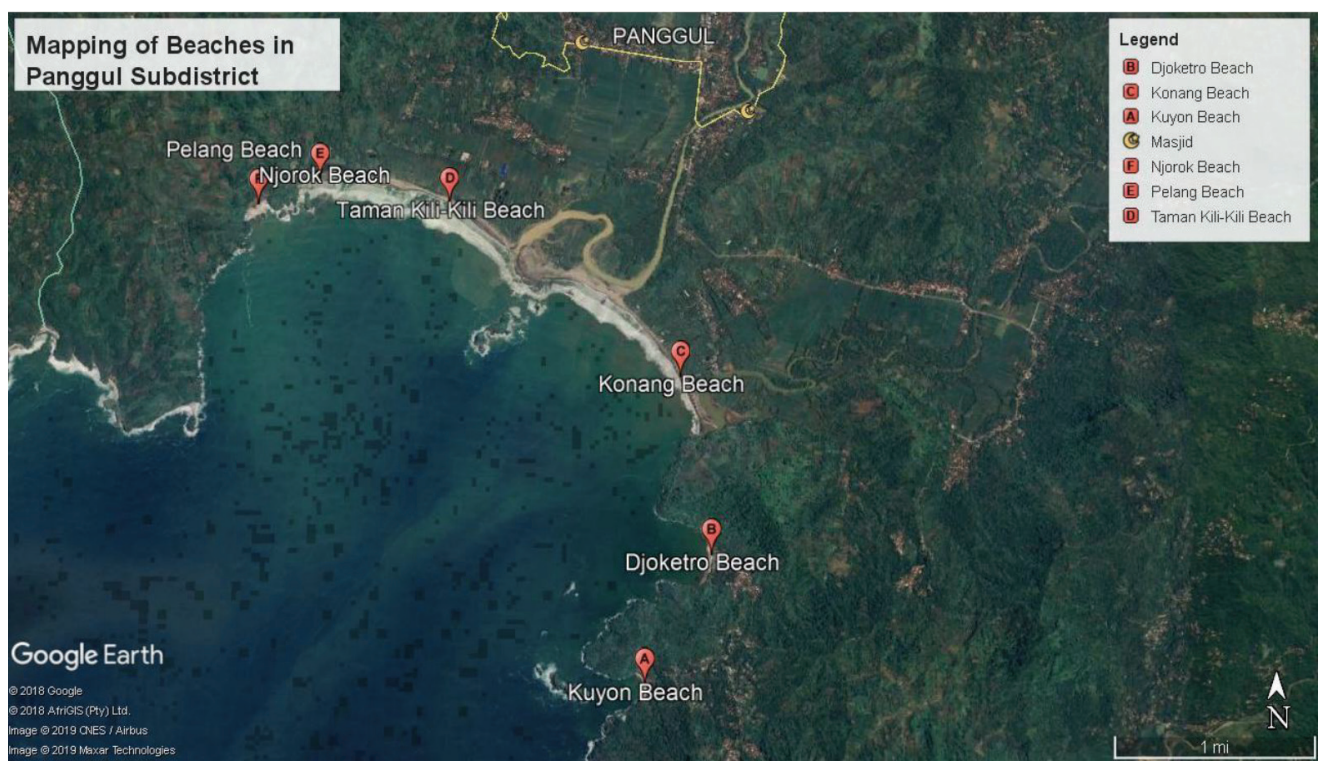

Figure 1: Coast of Panggul

Source: Google Earth

\section{Methods}

This research is a qualitative evaluation with a recursive approach.. In this approach, the formulation of research questions develops as the study progresses; analysis and data collection are performed together, and writing is often an evolutionary process, not a separate process that occurs at the end of the research (Veal, 2006). Data collection is by direct observation on the six beaches, interviews and documents. The objects of observation are the condition of soil, water, infrastructure, tourist facilities, tourist attraction sites, biodiversity, coastal stakeholder behavior, information media, and availability of recycling sites. Stakeholders include tourists, traders, local community, fishermen, and coastal managers. Tourist facilities include transportation, accommodation, souvenir shops, restaurants, toilets, prayer room, parking sites and tourism attractions.

Semi-structured interviews with destination managers, traders, fisherman, and tourists were carried out. Purposive sampling of informants was done by selecting those who have taken charge of coastal tourism management in Panggul for more than five years. Because
Njorok is an uninhabited beach, the informants consist of coastal managers, fishermen, and traders from Pelang, Konang, Taman Kilikili, Djoketro, and Kuyon. Documentation is done by taking pictures and perusing articles and scientific journals relevant to this study. Reliability is the consistency among a variety of data collection techniques (Neuman, 2014). Triangulation is used to measure the reliability by checking the responses among informants, and then between the findings of interviews, observations and document remain the same, similar, consistent, and stable. Data are in the form of words and images from documents, observations and transcripts, and are analyzed with an inductive approach. Inductive analysis primarily uses detailed readings of raw data to derive concepts, themes, or a model (Thomas, 2006). The data analysis process is as follows: 1) compiling, sorting and classifying; 2) coding (categorization), disassembling, reassembling (and arraying); 3) interpreting and elaborating 4) concluding (Neuman, 2014; Yin, 2016). Content analysis is also used to make interpretations of government policies because the units of analysis are Trenggalek governance rules on coastal ecotourism management and sustainable 
tourism in Panggul. Content analysis or document analysis is a method to systematically investigate texts. It not only analyzes the meanings that circulate in texts or textual content but also the context in which it was created (Leavy, 2017).

\section{Result and Discussion}

\section{Status of Coastal Tourism Managers in Panggul}

Each beach has a different management status. Kuyon, Djoketro, and Konang are fishing beaches, thus they are managed by fishing communities. Taman Kili-kili and Pelang beaches are managed by local governments. Njorok beach is uninhabited, has one access gate from Pelang beach, and is not under the management of any party. For further details, the coastal tourism attractions and management status in each beach are as follows (Table 1):

\section{Economic opportunity depends on coastal resource, tourism facilities, and local organization climate}

Konang beach is accessible to tourists, has feasible facilities, transportation, land use for food and beverage outlets, and coastal attractions that encourage economic opportunity. More than 20 small-scale restaurants are built along the beach. There is no ticket gate, but the coastal community often takes advantage of religious days, school holidays and musical performance events to charge entrance and parking fees as presented on Figure 2. The result of an interview with a representative of the fishing community that manages Konang is presented below:

"Fishing is one of the tourist attractions. They come to enjoy the beach, sunset, and taste the seafood. We can get around IDR 50,000 (\$4) per person that covers meals, parking, toilet, and boat rentals. We sell raw fish for them to

Table 1: Management status in the six beaches of Panggul district

\begin{tabular}{|c|c|c|c|}
\hline No. & Coastal Area & Coastal Tourism Attraction & Management Status \\
\hline 1. & Kuyon beach & $\begin{array}{l}\text { Marine products are primarily seaweeds; } \\
\text { coastal landscape is directly connected to } \\
\text { rice field area; brackish water sources on the } \\
\text { coastal area }\end{array}$ & Kuyon Fishing Groups \\
\hline 2. & Djoketro beach & $\begin{array}{l}\text { Seafood products are primarily lobster, Benur } \\
\text { "baby lobsters" and sweet shrimp; floating } \\
\text { houses; small-scale fish auction places }\end{array}$ & Djoketro Fishing Group \\
\hline 3. & Konang beach & $\begin{array}{l}\text { River empties to the sea; mangrove forest; sea } \\
\text { fish market; seafood culinary; boat tour }\end{array}$ & $\begin{array}{l}\text { Konang Fishing groups and } \\
\text { Sukorejo village community } \\
\text { RT } 36 \text { RW } 7\end{array}$ \\
\hline 4. & $\begin{array}{l}\text { Taman } \\
\text { beach }\end{array}$ & $\begin{array}{l}\text { Mangrove forest, sea turtle and hatchling } \\
\text { conservation }\end{array}$ & $\begin{array}{l}\text { Community watch group or } \\
\text { "Pokmaswas" consisting of } \\
\text { five members under Fisheries } \\
\text { Office of Trenggalek } \\
\text { governance }\end{array}$ \\
\hline 5. & Pelang beach & $\begin{array}{l}\text { A small coral island called Lempung Island, } \\
\text { similar to Tanah Lot in Bali, and other beautiful } \\
\text { coral islands; "Grobogan Sewu" beachside } \\
\text { waterfall; Swimming pool near the waterfall; } \\
\text { Hermitage Cave; The pine forest extends to } \\
\text { the beach; view of Bukit Karang }\end{array}$ & $\begin{array}{l}\text { Tourism and Culture Office } \\
\text { of Trenggalek governance } \\
\text { since January, } 1,2001 \text {. The } \\
\text { beach was managed by } \\
\text { village community from } \\
1986 \text { to } 2000\end{array}$ \\
\hline 6. & Njorok Beach & $\begin{array}{l}\text { Sea view; Craggy cliffs or broken beach; coral } \\
\text { rocks with green algae plants and small shells }\end{array}$ & No manager \\
\hline
\end{tabular}

Source: Data Processed by Researchers 
take home as well as cooked seafood and boat rentals if the tourist wants to go sightseeing around rivers. We also sell entrance tickets, but only on certain days, such as weekends, long holidays, art performances, culture and religious days. We invite our family group to manage the ticket gate and parking. If there are some traders outside Sukorejo Village, we will choose who gets to sell around Konang Beach. We will charge them for use of the land. Such fees are used to develop facilities to support coastal tourism on Konang beach."

Based on the interview, the destination managers of Konang Beach also manage land usage for the Panggul community that would open tourism business in the Konang Beach area. The fisheries sector in Konang Beach is integrated with the tourism sector. Local communities get their income not only as fishermen but also traders of raw seafood, opening food and beverage shops, tourism boats and land use for tourism business. It means that only the Konang fishing community and Sukorejo villagers are allowed to use and manage land for tourism business on Konang Beach.

Meanwhile, Pelang beach, which is managed by the Trenggalek Tourism and Culture Office, built some permanent buildings for members of the Panggul community who want sell food and beverage or souvenirs, as presented in Figure 3. Empty land around the beach is also available to Panggul residents for rent they must build their own short-term structures to carry out their economic activities. Approximately 15 permanent buildings designed for longterm use are at the beach entrance and near the waterfalls, whereas temporary buildings are irregularly located in places that disturb beach aesthetics, such as in the pine forest as illustrated in Figure 3. Panggul residents who want to use permanent buildings in strategic locations, such as near the access road, must pay government organizers IDR $150,000(\$ 10)$ per month or IDR 2,000,000 (\$136) per year. Sellers who prefer temporary buildings only have to pay
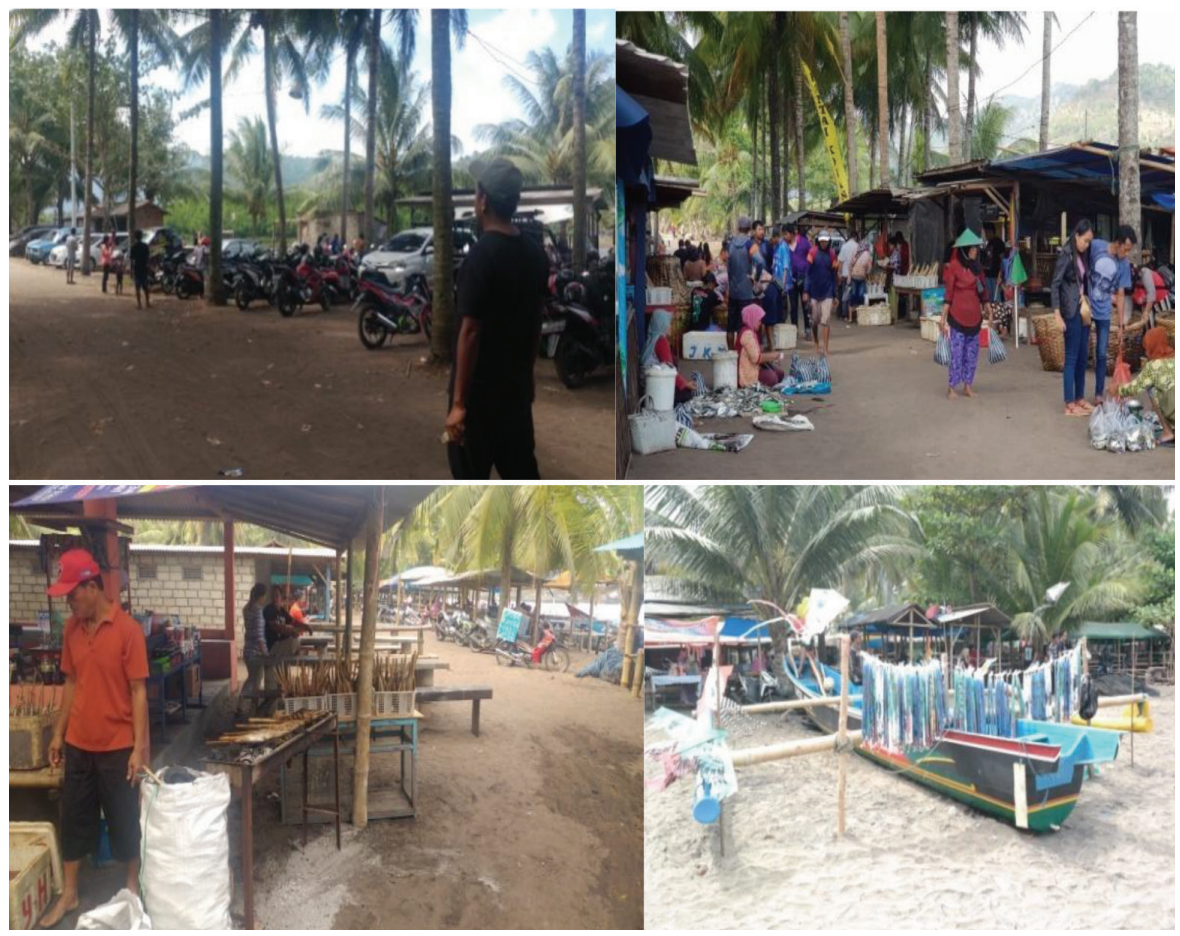

Figure 2: Land usage for coastal tourism in Konang Beach Source: Researcher documentation 


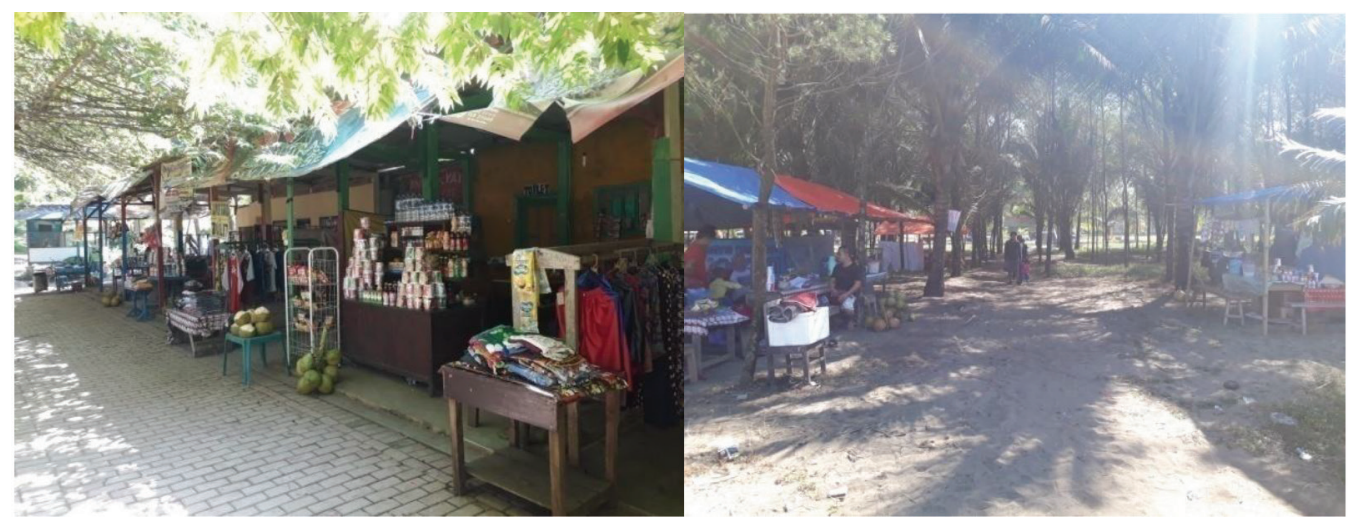

Figure 3: Land use for permanent buildings (left) and temporary buildings in Pine Forest (right) Source: Researcher documentation

IDR 20,000 (less of 2\$) per month. The Tourism Office provides jobs to Panggul residents as ticket post attendants, parking staff, and janitors. Because Pelang beach does not have fish, only light food and beverage and souvenirs shop are offered to residents in Pelang beach area. Njorok beach, is an additional attraction for tourists who come to Pelang, especially for adventure tourists. There is no tourism business activity in Njorok, so it has not generated income for the local community.

Meanwhile, Taman Kili-kili beach has been managed by five volunteers of the turtle conservation area and in education tourism. The sustainability of this conservation beach relies on the Panggul government budget, Fisheries Office Budget, Fisheries Ministry, Trenggalek Governance, tourist visits, community service programs, and government donations or company events for hatchlings as illustrated in the interview result with the leader of Pokmaswas below.

"Taman Kili-kili is built for sea turtle conservation which maintains biodiversity around the beach, it is not for commercialization. It is indeed for education tourism as well as coastal tourism and the income from tourist visits is used for operational purposes. Entrance ticket cost is IDR 7,500 (less than \$1) on weekdays and IDR 10,000 (less than \$1) on weekends. Tourists must pay IDR 100,000 (\$7) if they want to adopt four two-month old hatchlings; IDR 50,000 (\$4) for one fourmonth-old hatchling; IDR 250,000 (\$17) for one one-year-old hatchling. The monthly average revenue that Pokmaswas obtains is about IDR 300000 (\$21) to IDR 400,000 (\$27), which fluctuates and is insufficient for operational needs and human resource incomes".

The income of Taman Kili-kili is used for operational purposes and not profitable for the local people. Taman Kili-kili and Konang beach are similar in coastal management as community-based tourism, but Konang Beach is more profitable. Meanwhile, Kuyon and Djoketro beaches, although visited by tourists, lack facilities for tourism, as explained by a representative from Djoketro beach below.

"Kuyon is on the same route, after Djoketro, to our place. People or tourists must go through a cliffside path that is dangerous, the road is not feasible, and so few tourists come to our beach. Fishing offers a more sustainable livelihood than tourism. Our seas produce a lot of baby lobster which we export to Singapore and Vietnam. Tourist facilities are just toilets and one food and beverage shop without offering any special culinary spots. Even that is open in uncertain times. The residents of the village are not interested in tourism. Look at the road that goes to the beach." 
Fisheries is the main economic resource for the Kuyon and Djoketro community. Kuyon and Djoketro are less developed as tourism destinations. It is less interesting for tourists because of the lack of facilities and accessibility, as illustrated in Figure 4.

\section{Social Well-being and Local Custom Preservation Needs Community Participation}

The coastal community has faced social shifts. The adoption of fishing and marine technologies is becoming prevalent with the increasing use of powered boats and floating houses, as the same interview with the fisherman in Konang and Djoketro show:

"Floating houses on the three beaches are used for catching lobsters, baby lobsters, and other marine products. Fishermen who catch lobsters on Djoketro beach prefer to collect their catch with a net for a few days in a floating house. In the past, only fishing boats were used."

"In the middle of 2018, fishermen started offering boat tours to tourists. Fishermen in Kuyon, Djoketro and Konang beaches directly sent fish products to the Central District Market or fish auction. At present, these fishermen also directly sell to visitors who come to the beach."

In the case of Taman Kili-kili, before the establishment of the sea turtle conservation, the surrounding communities became hunters, sellers, and eaters of sea turtles, hatchlings, and eggs. The management member who pioneered sea turtle protection and preservation proposed an approach to the community customs as the interview result of the leader of Pokmaswas.

"At first, the community could not accept banning catching or eating turtles. Our approach was not scientific, but rather based on local traditions, suggesting that if community members caught or ate sea turtles, hatchlings, and eggs, then they would be in danger."

The members became more receptive to the local custom approach than the scientific approach. The surrounding community began to understand the importance of protecting sea turtles and stopped hunting, selling, and consuming them. The organizer previously released hatchlings through the "ucul-ucul" tradition. However, since 2018, the hatchlings were released two weeks after hatching. This caused environmental activists to protest, as they assumed it is a commercialized practice rather than a conservation act. The organizers have become skilled in environment and conflict management, with the training and workshops run by the Fishery and Marine Office, and Natural Resources Conservation Center. The knowledge transformation among the volunteers constructed a social perspective as they understood more conservation rules. It shows that community participation is the most important element in community-based tourism

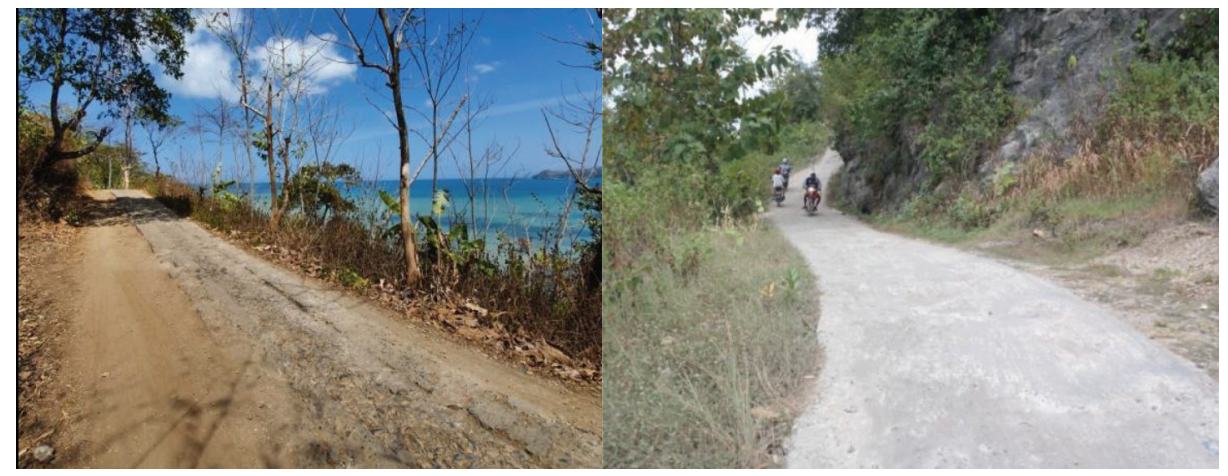

Figure 4: Road to Djoketro and Kuyon beaches

Source: Researcher documentation 
for sustainable development because they are the main actors in the operational system. Related to tourism, parameters in community participation in tourism development include planning and decisionmaking, implementation, benefit sharing, and evaluation (Oktami, Sunarminto, \& Arief, 2018: Musadad, 2018).

According to the destination management organizer, each beach community except for Pelang are directly involved in decisionmaking, implementation, benefit taking, and evaluation. The organizers involve younger members in management, as shown in an interview with a trader in Konang and one of volunteers in Taman Kili-kili.

"Youth organization members in Sukorejo Village also help in managing entrance tickets and parking during peak season. Some of them also help in restaurants and sell the fish. They make regular contributions in organizing annual traditional ceremonies on the beach such as Baritan or Alms Sea".

"Our kids are involved in some activities, such as helping with ticket entrance, we involve the surrounding community to manage mangroves and clean the garbage along the coast."

Community participation in Pelang is categorized into implementation and benefit taking. The Tourism Office of Trenggalek, as the managers of Pelang, conducts planning, decision making, and evaluation. But, issues that could threaten development include: a. Dispute between the Forestry Office, Tourism Office and Fishery Office of Trenggalek over land use in Taman KiliKili. Konang land is under the Forestry Office. The Tourism Office of Trenggalek has tried to develop Taman Kili-kili and Konang for tourism. However, the current management of Taman Kili-kili is unwilling to transfer its authority to the Tourism Office over fears of exploitation, overcapacity, and high level commercialization, which could cause destruction to the coastal ecosystem, biodiversity, sea turtles and hatchling population.

b. Since October 2019, the shrimp pond owner has closed the road to Taman Kilikili beach that is accessible by cars. Tourists that drive to the beach have to park far away from the beach. The road that is available to tourists is sandy and suitable only for motorcycles, as illustrated in Figure 5.

\section{Shrimp ponds and littering poses problems to environmental quality and sustainable coastal tourism}

Regarding environmental conservation, the first challenge in the coastal tourism management in Panggul is the existence of shrimp ponds scattered along the coast since 2018. There are eight ponds on Konang beach, two ponds on Djoketro beach, six ponds on Taman Kili-kili beach, and one near Pelang beach, as illustrated in Figure 6. Kuyon and Njorok beaches are still free from the reach of shrimp farmers due

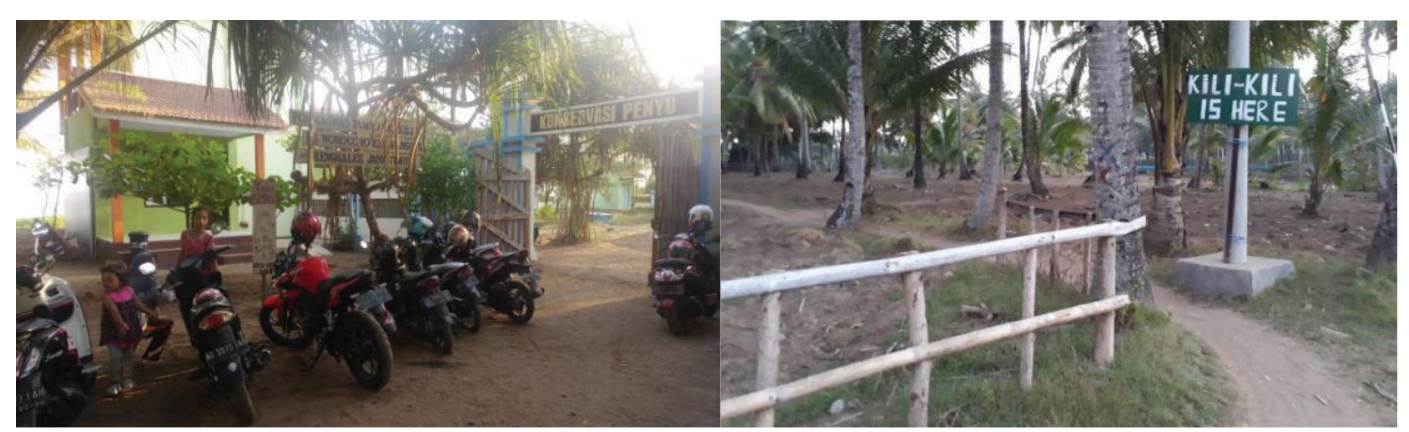

Figure 5: Unorganized parking lots and narrow entryways in Taman Kili-Kili beach Source: Researcher documentation 
to difficult road access. Konang beach has the largest number of shrimp ponds because it is connected to the river mouth, therefore allowing pond water to flow. This type of shrimp farming system in Panggul is at a large or semi-intensive scale and uses a non-environmental friendly mixture (Lima \& Baley, 2015). The characteristic of this business system include being owned by agents of large-scale farmers; land areas of 6-45 ha; intensive feeding practices using vitamins made from chemicals; fenced buildings to limit territory and are heavily guarded by officers, because they feel they are legal; shrimp products sold to cities and not to residents; and polluted water environment, mangrove forest, and land around the coastal area (Lima \& Baley, 2015).

The river, which empties into the sea at Djoketro beach, is dark blue in color, forms foam waste, and emits a pungent odor (Figure 7). In addition to shrimp ponds, marine coastal pollution at Djoketro beach is also caused by garbage from fishing. Such garbage is scattered along the coastal area without proper waste management, as shown in Figure 8. Similar to Taman Kili-kili beach, shrimp ponds are located only $500 \mathrm{~m}$ from the conservation center and passed by visitors on the main road to the conservation area. Shrimp ponds also emit a pungent odor, affect water quality, and deteriorate soil, as displayed in Figure 7.

However, such ponds have not harmed the turtle conservation area yet because a large sandy bank stands between the shrimp ponds and the conservation area. However, shrimp ponds affect the sea turtle habitat and the species that frequent the beach, both of which have been identified as priorities for conservation, as shown in the interview with the leader of Pokmaswas.

"Shrimp ponds are suspected of causing changes and (the number of) certain types of turtles are decreasing. Six to seven species of sea turtle used to exist. The most dominant species are Lekang, Hawksbill, and Leatherback turtles. In 2017, as many as 1,000 green turtles were released by managers, tourists, and environmental activists in Taman Kili-kili beach, indicating that the beach is popular because of its ecology and physicality. However, with the

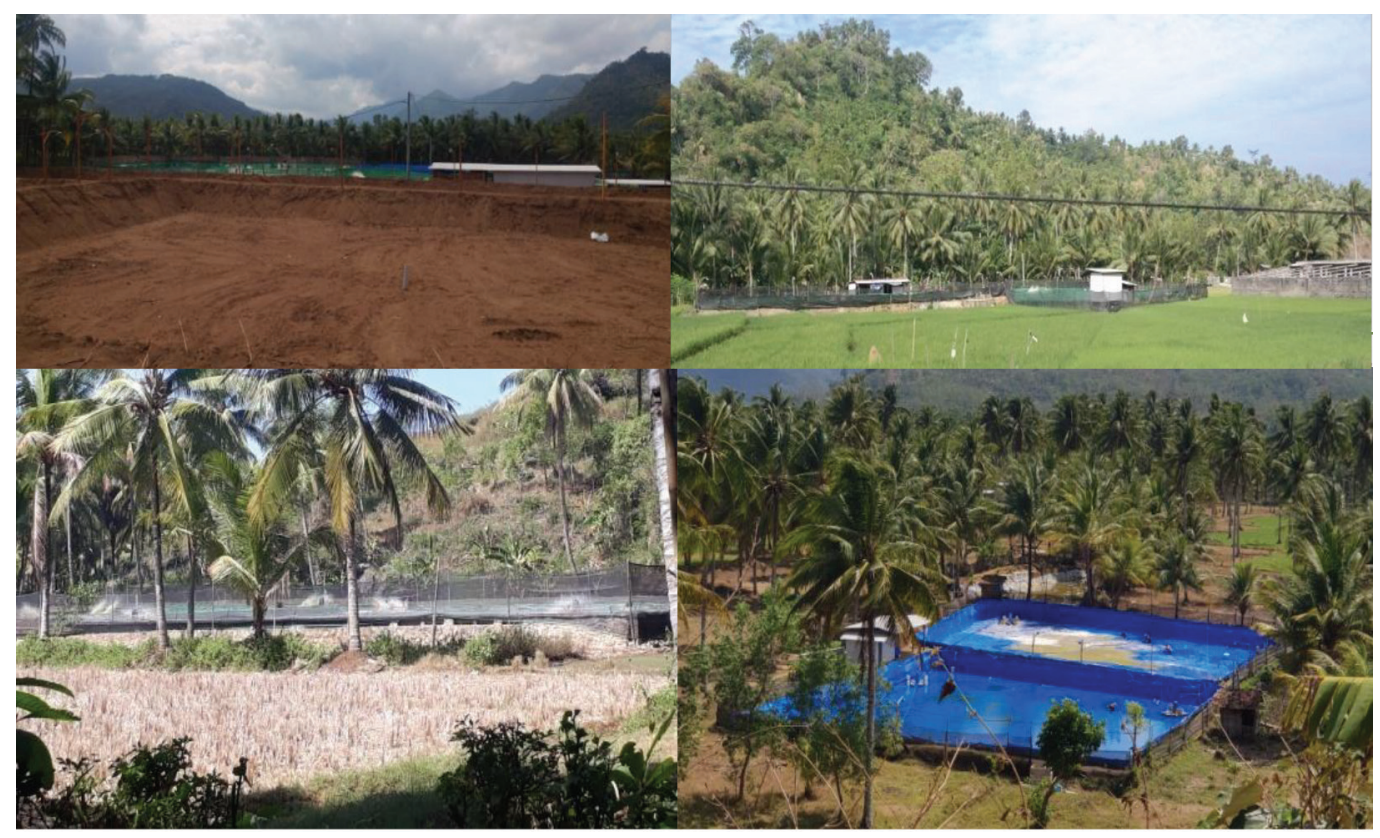

Figure 6: Shrimp ponds in Djoketro, Konang, Taman Kili-kili, and Pelang beaches Source: Researcher documentation 


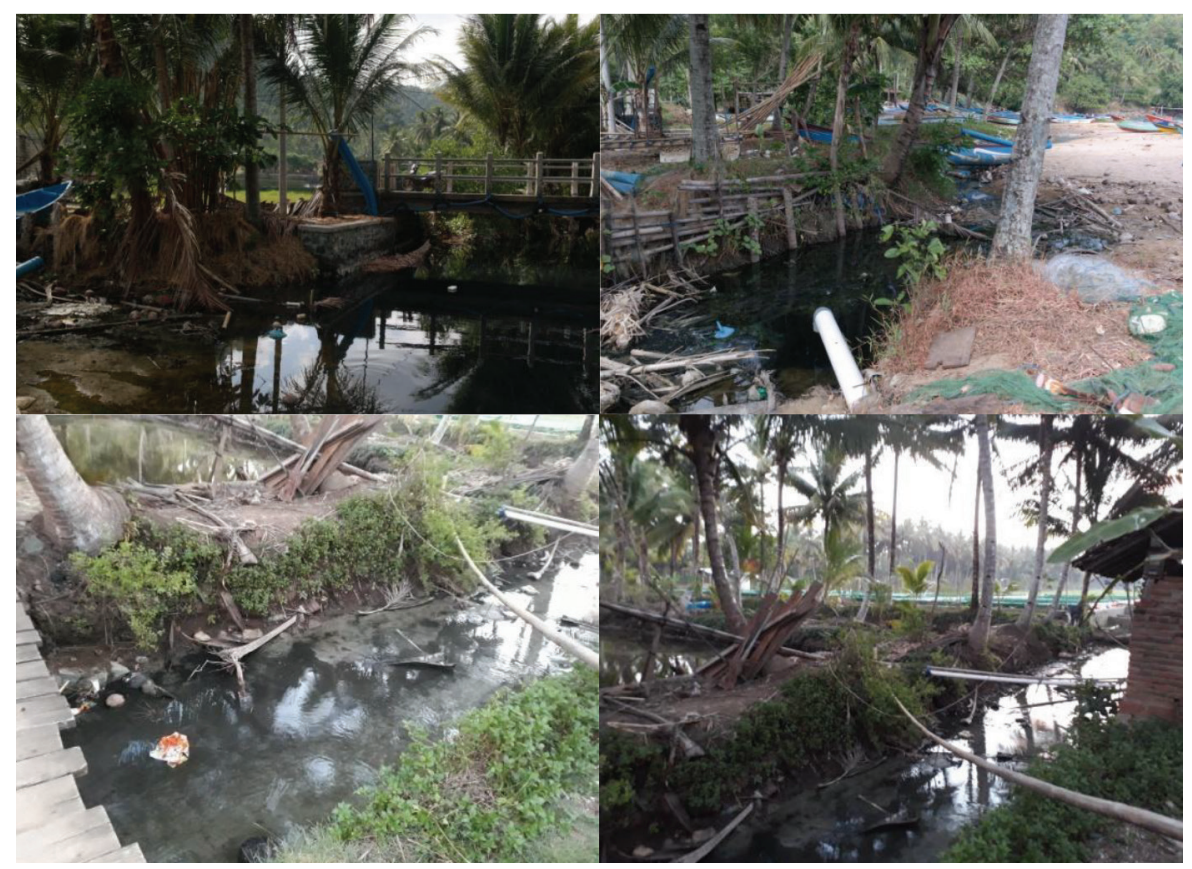

Figure 7: Shrimp pond waste in Djoketro beach (above) and the coast around Taman Kili-kili beach (below) Source: Researcher documentation

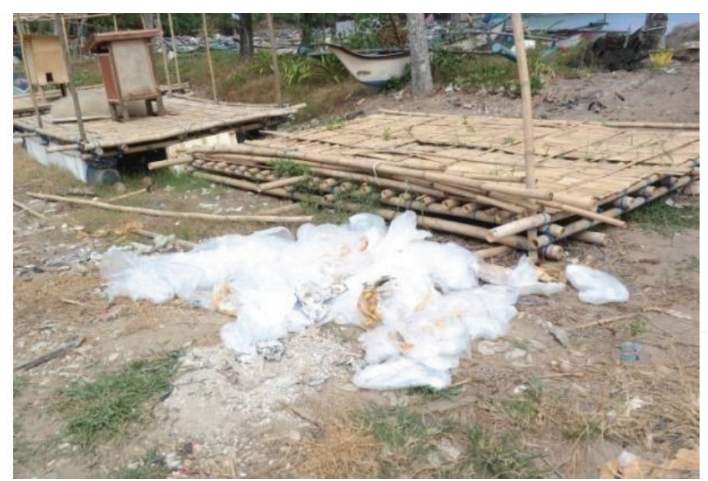

Figure 8: Garbage disposal from fishing activities in Djoketro beach Source: Researcher documentation

existence of shrimp ponds and the change of land function into coconut plantations, Lekang is the only turtle species that still wants to lay eggs on Taman Kili-kili beach. Since then, Pokmaswas has been preserving the conservation area by planting additional more spruce shrimp trees and pines. Such additions allow existing species and other types of sea turtles to come back to Taman Kili-kili beach."

On Konang beach, garbage pollution is observed. Traders leave piles of garbage at several spots of the beach, and tourists also leave litter, as shown in Figure 9. Motorcycle parking causes land degradation. Land usage for business, toilet, and parking is built approximately $20 \mathrm{~m}$ from the coastline. 


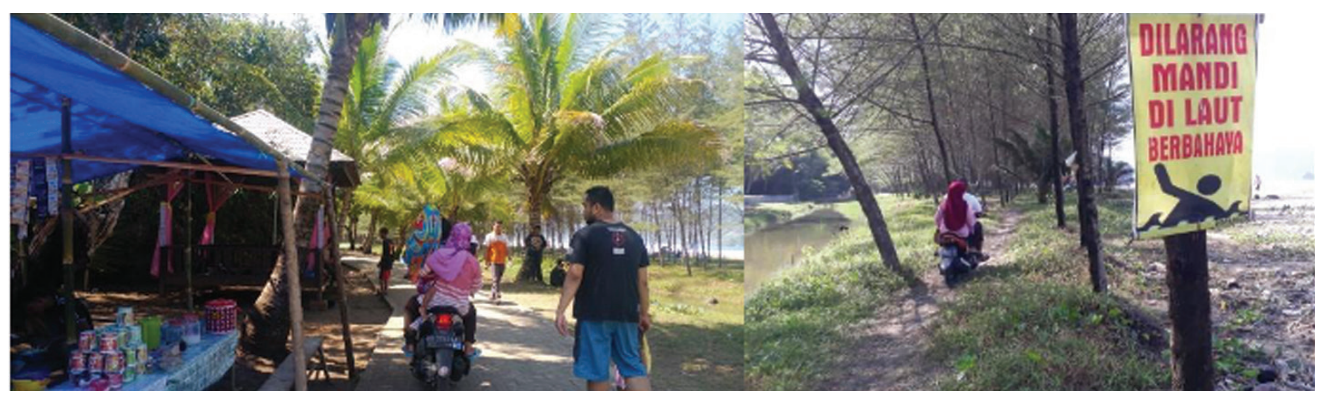

Figure 9: Waste behind food stalls and Konang beach parking spot Source: Researcher documentation

Climate change has influenced the movement of sea turtle on Konang, as the the Konang destination organizer says:

"In 2010, several turtles laid eggs on Konang beach. However, no more turtles came after that, due to the various illuminated areas on the coast. Meanwhile, sea turtle conservation in Taman Kili-kili beach is still in good condition because the area remains dark. Lighting is found in only one guard building. Surrounding vegetation is maintained, starting from coconut trees, pandan leaf plants, pine trees, and grasses along the beach. Its management community also plants mangrove trees along the coast for a cool temperature. In addition, the beach is regularly cleaned; trash from ships, especially plastic waste around the beach that is dangerous for sea turtles, is properly disposed of. Water flow for hatchlings is regularly replaced".

Pelang has not been affected by the existence of shrimp ponds because it is separated by hills. However, tourist litter and temporary traders leave piles of garbage at several spots in Pelang. Water quality under the bridge across the river that empties into the sea, swimming pools, pine forests, and waterfalls are also deteriorating due to garbage waste. Trash bins in Pelang are provided at several spots, but piles of garbage remain beside food stalls, as shown in Figure 10.

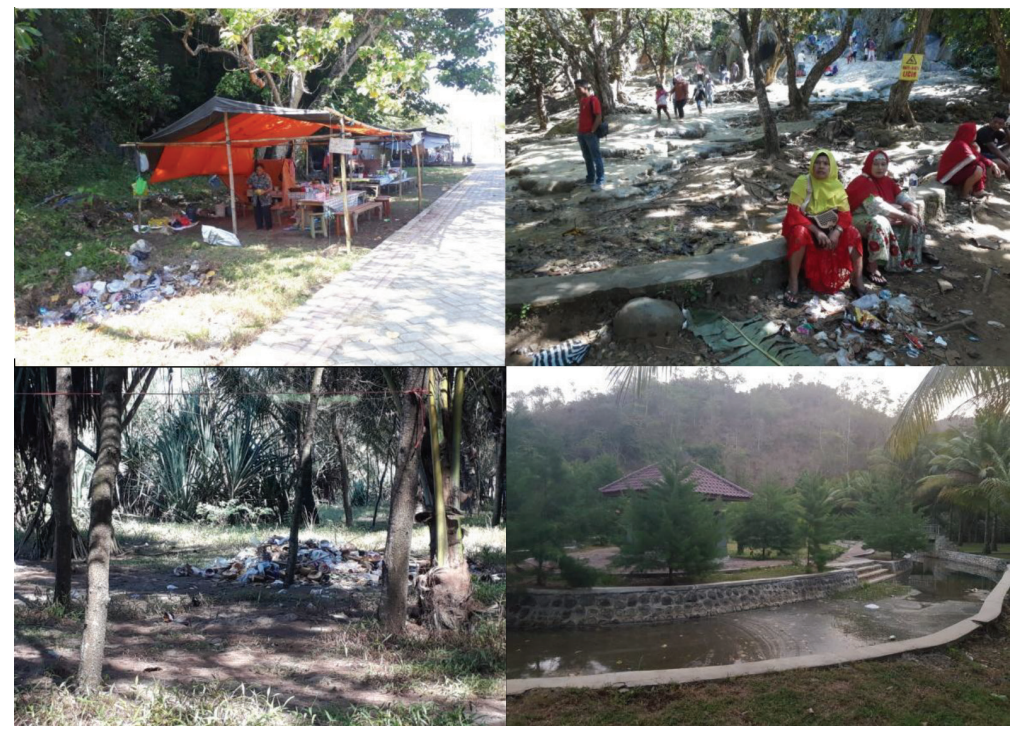

Figure 10: Trader and tourist waste and river water waste around Pelang beach Source: Researcher documentation 


\section{The Government of Trenggalek's lack of action in sustainable tourism development policies}

The role of the Trenggalek regency government in making local tourism development regulations is provided for in the Trenggalek regency regional regulation No. 26 of 2016 regarding the 2017-2031 Regional Tourism Development Master Plan. This regulation is based on Law No. 10 of 2009 regarding Tourism that every region must have a tourism master plan for a certain period. Part Six: Development of Environmental Responsibility, Article 55 reads as follows:

"The direction of policy on the development of environmental responsibility, as referred to in Article 41 letter E, is manifested in the form of developing a tourism business management which refers to the principles of sustainable tourism development, a code of ethics for world tourism and a green economy."

However, the regional regulation of Trenggalek regency lacks explanation about what should be done in sustainable tourism development. The regulation only discusses destination tourism development in general. This limitation can impact the absence of standard rules in the implementation of sustainable tourism development in the field. The regency government issued the Trenggalek Regulation No. 7 of 2010 concerning Management of Fisheries, Coastal Areas, and Small Islands. The purpose of the regulation relates to the protection of local customs or culture, prevention of damage to resources due to exploitation, provision of access to infrastructure development in the management of coastal areas, and the development of sustainable and community-based coastal management. In fact, there are no detailed guidelines and master plan on the sustainable community-based coastal management provided by the local government. The role of local government in coastal ecotourism management includes: the Fisheries Office often provides training and counseling for Pokmaswas on sustainable management; village government of Panggul contribute to provide tourist facilities (gazebos, hatchlings, turtle ponds, worship places, toilets, signboards, joglo education buildings) in Taman Kili-kili; meanwhile, the Tourism Office of Trenggalek provided feasible facilities (prayer rooms, toilets, large parking areas, tourist spots, bridges, swimming pools, and gazebos), attraction, and services in Pelang. The government has developed the tourism sector in Taman Kili-kili and Pelang. Even though there is involvement of the government, it does not guarantee sustainable management. It was shown that tourists brought motorcycles into pedestrian and biodiversity areas as illustrated in Figure 11. Even the pine forest, cultivated to prevent erosion, was altered by traders encroaching onto the land. There are no government officers to put the traders in order, especially the temporary traders who set up shop on every spot in Pelang. There is no government regulation on sustainable shrimp pond management to prevent

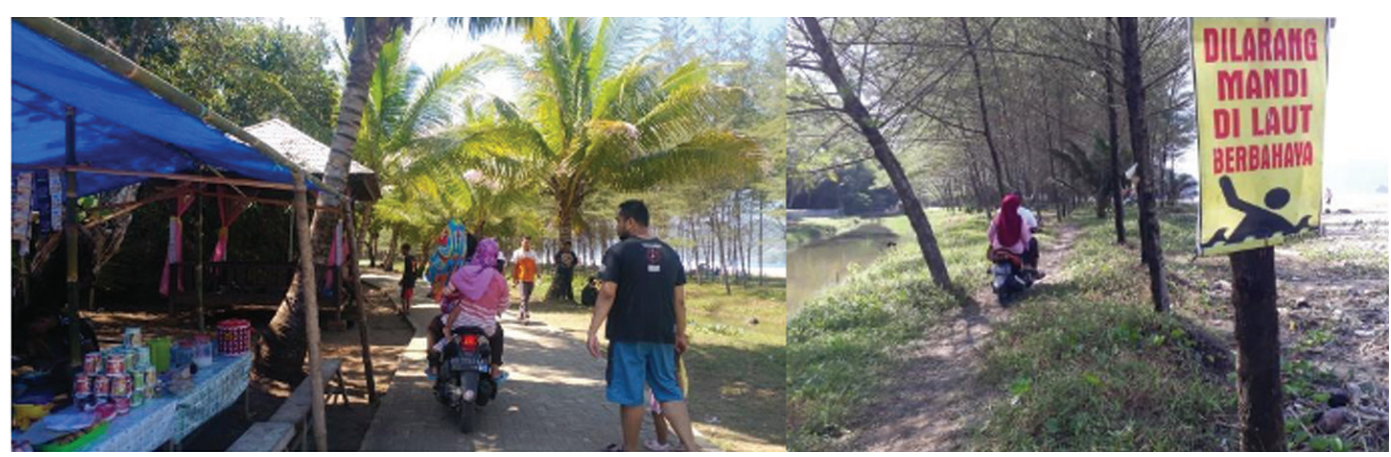

Figure 11: Misuse of pedestrian access by visitors in Pelang Source: Researcher documentation 
coastal environment degradation. Shrimp ponds are spread along the Panggul coast without limitation and pose a threat to sustainable coastal tourism.

Zoning according to the regulation of the Ministry of Maritime Affairs and Fisheries of the Republic of Indonesia No. 23 /Permen-KP /2016 concerning the Management of Coastal Areas and Small Islands prioritizes conservation areas, livelihood space and land access for small traders, traditional fishermen, sustainable marine tourism, and public infrastructure. The regulation states that local governments are required to arrange a zone. The regional regulation in East Java Province No. 1 of 2018 regarding the zoning plans for coastal areas and small islands in East Java Province in 2018-2038 maintains the use of coastal space for permitted tourism activities, unpermitted activities, and activities that are allowed after obtaining permits. Zoning regulations from the Ministry of Maritime Affairs or local governments are necessary conditions for successful coastal management and local culture maintenance (Glaser et al., 2015). Government rules and policies related to coastal management should avoid conflict, pay attention to land-use and the human dimension for sustainability from the environmental dimension (Neumann, 2017). However, coastal features in the Trenggalek regency that are included in the regulation remain limited to beaches, which are prioritized by the Trenggalek tourism and cultural office, such as Karanggongso, Prigi, and Ngampiran beaches. Other beaches, including Panggul, have no zoning management rules. One of the consequences of this lack of regulation is uncontrolled shrimp ponds that risk conservation viability. A leader of the Pokmaswas says:

"In the future, when the waste from shrimp ponds is not managed, it will have a negative impact on the sustainability of conservation. The disposal of pond waste along the river that empties into Taman Kili-kili beach area will pollute the core conservation area"
Coastal zone management is needed for distinguishing the type of beaches used for conservation zone, recreation zone, or coastal resident zone. The objective is to regulate beach usage according to function so that there is no destruction either in ecology or social-cultural aspects. The lack of government action in regulation risks low community resilience and regeneration in coastal tourism management that affect not only conservation viability but also tourism viability so that local residents are unwilling to use coastal tourism as their main economic source. The leader Pokmaswas says:

"Local residents have not been aware of the economic potential of tourism. From 50 volunteers in 2010, there are now 5 volunteers in 2019. They prefer to be farmers and fishermen, which they assume provides more stable income. It is the same with (people in) Konang, Djoketro, and Kuyon that prefer to be fishermen, selling food or raw fish just as additional income."

The reluctance of coastal residents of Panggul is due to the lack of regulation in strengthening local community organizations by the local government. There is no contribution from the local government to improve infrastructure, road and transportation to Djoketro and Kuyon. Even if there is an improvement project, it is based on political needs as the result an interview with fishermen in Djoketro and Kuyon.

\begin{abstract}
"The village government has never cared about the construction of the Djoketro and Kuyon road. How can we depend on tourism for our livelihoods? Tourists would not be eager to endanger themselves to visit Djoketro and Kuyon. As for the repair of the road, it is repaired by members of political parties related to their campaign interests, and it becomes seasonal, there are no regular development programs from the village, district or provincial governments."
\end{abstract}

The land around Konang beach is owned by the Forestry Office. There is no certainty for 
Konang residents how long they can use the land for tourism. A Sukorejo Villager says:

"Local communities, specifically Sukorejo Hamlet, are allowed to run their business.

However, the government can evict them anytime if the land will be used for certain purposes."

The organization in the local government increases economic, socio-culture and ecology risk that affect tourism development among beaches in Panggul. This is a challenge for sustainable tourism development that must be overcome by regulations and community-based tourism development plans.

\section{Conclusion}

Based on the result of the study, the status of coastal management in Panggul is divided into two types, under government and local community. Local community management tends to be community-based tourism. Community-based tourism is a key element in the management of coastal eco-tourism, which is hoped to be able to provide economic welfare, social, cultural and environmental protection. Coastal ecotourism is indeed a strategy to manage sustainable coastal tourism, but it becomes unbalanced without local institution strengthening and policy governance. Sustainable shrimp ponds management, coastal zone management and eco-land use must be the focus of government development policies. This study proves that even though there have been changes to the economy and social shifts in coastal communities, without government regulations regarding the provision of proper infrastructure; supporting development funds, strengthening local institutions and community capacity and waste management, environmental and tourist facilities quality suffer, leading to a failure to realize sustainable tourism. This research proves that government regulation is needed for sustainable tourism so that economic, social wellbeing and cultural, environmental quality is maintained. In addition, community participation is required for the sustainability of social wellbeing and cultural preservation. Coastal ecotourism management for sustainable tourism must give economic opportunities, ecological protection, social wellbeing, local custom preservation and community participation. The limitations of this study, firstly, the absence of quantitative data on economic income, environmental quality, social well-being and cultural impact. Second, there is no involvement of informants from the government side, only relying on content analysis of government regulations. Numerical data and government involvement as informants in future studies could add new insights to coastal ecotourism management. By considering the result of this study, destination managers and the government can collaborate to formulate policies in coastal ecotourism management.

\section{Acknowledgements}

The authors would like to thank Vocational College, Universitas Gadjah Mada, Yogyakarta, Indonesia for funding support through the Competitive Grants Scheme.

\section{References}

Badan Pusat Statistik (BPS) Kabupaten Trenggalek. (2017). Jumlah Pengunjung Obyek Wisata di Kabupaten Trenggalek 2015: The Number of Tourist Resort Visitors In Trenggalek Regency, 2015. https:/trenggalekkab.bps.go.id/statictable/ 2017/01/25/264/-jumlah-pengunjungobyek-wisata-di-kabupaten-trenggalektrenggalek-2015.html

Badan Pusat Statistik (BPS) Kabupaten Trenggalek. (2018). Kecamatan Panggul dalam angka 2018. Katalog BPS: 1102001.3503010 .

Badan Pusat Statistik (BPS) Kabupaten Trenggalek. (2019). Kabupaten Trenggalek dalam angka 2019: Trenggalek Regency in Figures 2019. ISBN 0215.6210

Bambang, A. Wibowo, et al. (2018). IOP Conf. Ser.: Earth Environ. Sci. 116012051 
Famuditi, Taye O. (2016). Developing local community participation within shoreline management in England: The role of Coastal Action Groups (Doctoral thesis, University of Portsmouth, United Kingdom). https://researchportal.port.ac.uk/portal/ en/theses/developing-local-communityparticipation-within-shoreline-managementin-england(34babc31-eb43-4cf3-8a635cdd1c3ea30f).html

Glaser, M., Breckwoldt, A., Deswandi, R., Radjawali, I., Baitoningsih, W., \& Ferse, S. C. A. (2015). Ocean \& coastal management of exploited reefs and fishers: A holistic view on participatory coastal and marine management in an Indonesian archipelago. Ocean and Coastal Management, 116, 193213. https://doi.org/10.1016/j.ocecoaman. 2015.07.022

Gollan, N., Voyer, M., Jordan, A., Barclay, K., South, N., Fisheries, I., Bay, N. (2019). Maximizing community wellbeing: Assessing the threats to the benefits communities derive from the marine estate. Ocean and Coastal Management, 168(July 2018), 12-21. https://doi.org/10.1016/j.oce coaman.2018.10.020

Halim, H. S. (2017). Scrutinizing coastal ecotourism in Gili Trawangan, Indonesia. International Journal of Marine Science, 7(25), 247-259. (DOI: 10.5376/ ijms.2017.07.0025)

Hakim, M., Hakim, A., Hakim, L., Harahab, N. (2018). Coastal Tourism Management Model toward developing independent tourist village in Central Lombok District, Indonesia. Resources 2018, 7, 69; DOI: 10.3390 /resources 7040069

Handayawati, H. (2010). "Potensi Wisata Alam Pantai-Bahari. PM PSLP PPSUB".

Jones, Andrew \& Phillips, Michael. (2011). Disappearing destinations: Climate change and future challenges for coastal tourism. UK: CAB International.
Karnauskaitè, D., et al. (2018). Assessing coastal management case studies around Europe using an indicator based tool. Journal of Coastal Conservation, 22, 549-570 https://doi.org/10.1007/s11852-018-0597-x

Leavy, Patricia. (2017). Research design: Quantitative, qualitative, mixed methods, art-based, and community-based participatory approaches. New York: The Guilford Press.

Lima, J. S. G., Bailey, C. (2015). Shrimp farming as a coastal zone challenge in Sergipe State, Brazil: Balancing goals of conservation and social justice. In Finkl, C., Makowski, C. (Eds.), Environmental management and governance. Coastal Research Library, 8. Springer.

Masud, M. M., Aldakhil, A. M., Nassani, A. A., \& Azam, M. N. (2017). Community-based ecotourism management for sustainable development of marine protected areas in Malaysia. Ocean Coastal and Management, 136, 104-112.

Mcelduff, L., Peel, D., Ritchie, H., Lloyd, M. G., Mcelduff, L., Peel, D., Lloyd, M. G. (2016). The Octagon Values Model: Community resilience and coastal regeneration The Octagon Values Model: Community resilience and coastal regeneration. Urban, Planning and Transport Research, 0020, 1-25. https://doi.org/10.1080/21650020.20 15.1124735

Musadad. (2018). Community participation in nature tourism development: Lessons from Pindul Cave in Yogyakarta, Indonesia. Kawistara 5415, 160-168. https://doi. org/10.22146/kawistara.27957

Muzaki, Nasrulloh. (2017). Kajian Potensi Wisata Pantai Kabupaten Trenggalek. Swara Bhumi, 5(IV, 2017), 61 - 66.

Neumann, B. (2017). Strong sustainability in coastal areas: A conceptual interpretation of SDG 14. Sustainability Science, 12(6), 1019-1035. https://doi.org/10.1007/s11625017-0472-y 
Neuman, W. Lawrence. (2014). Social Research Methods: Qualitative and Quantitative Approaches ( $7^{\text {th }}$ ed.). UK: Pearson.

Nuzula, et al. (2017). Strategi Pengelolaan EkowisataPesisirDiTamanNasionalBaluran Dengan Metode Multi Dimensional Scalling. Coastal and Ocean Journal, 1(2) Desember 2017: 83-90.

Oktami, E. A., Sunarminto, T., \& Arief, H. (2018). Community participation in ecotourism development Ir $\mathrm{H}$ Djuanda Forest Park. Media Konservasi, 23( 3) Desember, 236-243.

Papageorgiou, M. (2016). Coastal and marine tourism: A challenging factor in Marine Spatial Planning. Ocean \& Coastal Management, 129, 44-48. doi: 10.1016/j. ocecoaman.2016.05.006

Pemerintah Kabupaten Trenggalek. (2010). Peraturan Daerah Kabupaten Trenggalek Nomor 7 Tahun 2010 Tentang Pengelolaan Perikanan, Wilayah Pesisir dan Pulau - Pulau Kecil.

Pemerintah Kabupaten Trenggalek. (2016). Peraturan Daerah Kabupaten Trenggalek Nomor 26 Tahun 2016 tentang Rencana Induk Pembangunan Kepariwisataan Daerah Tahun 2017-2031.

Peraturan Menteri Kelautan dan Perikanan Republik Indonesia Nomor 23/PermenKP/2016 tentang Perencanaan Pengelolaan Wilayah Pesisir dan Pulau-Pulau Kecil.

Prasetyo, Dedik, E. (2013). Potensi Kepariwisataan Pantai Konang sebagai Daerah Tujuan Wisata di Kecamatan Panggul Kabupaten Trenggalek. Swara Bhumi, 2(2), http://jurnalmahasiswa.unesa. ac.id/index.php/swara-bhumi/article/ view/2541

Riniwati, H., Harahab, N., \& Abidin, Z. (2019). A vulnerability analysis of coral reefs in Coastal ecotourism areas for conservation management. Diversity, 11(107), 1-15. doi:10.3390/d11070107
Rudiastuti, A. W., et al. (2018). IOP Conf. Ser.: Earth Environ. Sci., 148012013.

Sarfaraz Hashemkhani Zolfani, Maedeh Sedaghat, Reza Maknoon \& Edmundas Kazimieras Zavadskas. (2015). Sustainable tourism: A comprehensive literature review on frameworks and applications. Economic ResearchEkonomska Istraživanja, 28(1), 1-30. DOI: 10.1080/1331677X.2014.995895

Schernewski, G., \& Katar, M. (2014). Application and evaluation of an indicator set to measure and promote sustainable development in coastal areas. Ocean \& Coastal Management, 101, 2-13. https:// doi.org/10.1016/j.ocecoaman.2014.03.028

Seba, Jaime, A. (2012). Ecotourism and sustainable tourism: New perspectives and studies. Canada: Apple Academic Press.

Setyorahmah, Ilham, D. (2017). Promosi Obyek Wisata (Studi DeskriptifTentang Efektivitas Promosi Obyek Pantai Pelang Oleh Dinas Pariwisata Pemuda dan Olahraga Kab. Trenggalek). Fakultas Vokasi, Universitas Airlangga. (Unpublished).

SUSTAIN partnership. (2012). Measuring coastal sustainability, a guide for the selfassessment of sustainability using indicators and a means of scoring them. SUSTAIN Project/INTERREG IVC.

Tegar, R., Dimas., \& Gurning, R. O. Saut. (2018). Development of marine and coastal tourism based on blue economy. International Journal of Marine Engineering Innovation and Research, 2(2) Mar. 2018, 128-132. (ISSN: 2541-5972, eISSN: 2548-1479.

Thomas, David, R. (2006). A general inductive approach for analyzing qualitative evaluation data. American Journal of Evaluation, 27(2), 237-246. DOI: $10.1177 / 1098214005283748$

Tuwo, A. (2011). Pengelolaan ekowisata pesisir dan laut: Pendekatan ekologi, sosialekonomi, kelembagaan, dan sarana wilayah. Brilian Internasional. 
Tuzaroh, Arifa. (2015). Analisis Pengembangan Ekowisata Bahari Taman Kili-Kili Sebagai Daerah Tujuan Wisata Di Kecamatan Panggul Kabupaten Trenggalek. Swara Bhumi, 3(3), 7-20.

United Nations Environment Programme (UNEP). (2009). Sustainable Coastal tourism: An integrated planning and management approach. France.

Veal, A. J. (2006). Research methods for leisure and tourism A practical guide ( $3^{\text {rd }}$ ed.). England: Pearson Education.
Wahyunanto, S., \& Topowijono. (2018). Penerapan hygiene dan sanitasi dalam upaya peningkatan mutu kualitas food and baverage (Studi pada Pantai Konang Desa Ngelebeng Kecamatan Panggul Kabupaten Trenggalek). Jurnal Administrasi Bisnis (JAB), 58(2) Mei, 146-154

World Tourism Organization (WTO). (2013). Sustainable tourism governance and management in coastal areas of Africa. Madrid: UNWTO.

Yin, Robert, K. (2016). Qualitative research from start to finish (2nd ed.). USA: The Guilford Press. 